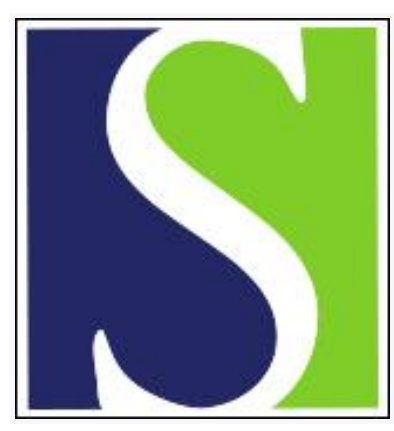

Scand J Work Environ Health 1998;24(6):481-485

https://doi.org/10.5271/sjweh.372

Issue date: Dec 1998

Particle-bound benzene from diesel engine exhaust

by Muzyka V, Veimer S, Shmidt N

Key terms: air pollution; bus maintenance worker; diesel exhaust particles; diesel gas phase emission; occupational exposure

This article in PubMed: www.ncbi.nlm.nih.gov/pubmed/9988090

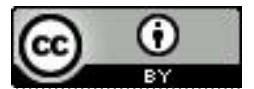




\title{
Particle-bound benzene from diesel engine exhaust
}

\author{
by Vladimir Muzyka, DSc, ${ }^{1}$ Sonja Veimer, PhD, ${ }^{1}$ Nadja Shmidt, $P h D^{1}$
}

\author{
Muzyka V, Veimer S, Shmidt N. Particle-bound benzene from diesel engine exhaust. Scand J Work Environ Health \\ $1998 ; 24(6): 481-485$.
}

\begin{abstract}
Objectives The large surface area of the carbon core of diesel exhaust particles may contribute to the adsorption or condensation of such volatile carcinogenic organic compounds as benzene. The attention of this study focused on determining the distribution of benzene between the gas and particulate phases in the breathing zone of bus garage workers.

Methods Benzene and suspended particulate matter were evaluated jointly in the air of a municipal bus garage. Personal passive monitors were used for benzene sampling in the breathing zone of the workers. Active samplers were used for sampling diesel exhaust particles and the benzene associated with them. The benzene levels were measured by gas chromatography.

Results Diesel engine exhaust from buses was the main source of air pollution caused by benzene and particles in this study. The concentration of benzene in the gas and particulate phases showed a wide range of variation, depending on the distance of the workplace from the operating diesel engine. Benzene present in the breathing zone of the workers was distributed between the gas and particulate phases. The amounts of benzene associated with particles were significantly lower in summer than in winter.

Conclusions The particulate matter of diesel exhaust contains benzene in amounts comparable to the concentrations of carcinogenic polycyclic aromatic hydrocarbons (PAH) and the usually found nitro-PAH. The concentration of benzene in the gas phase and in the suspended particulate matter of air can serve as an additional indicator of exposure to diesel exhaust and its carcinogenicity.
\end{abstract}

Key terms air pollution, bus maintenance workers, diesel exhaust particles, diesel gas phase emission, occupational exposure.

Contemporary methodology for cancer risk assessment includes determining complete exposure levels through environmental monitoring. Continuing efforts have been made to identify hazardous compounds and to recognize the sources and the occurrence of these agents. Diesel exhaust is an example of a complex mixture that is carcinogenic for animals and probably carcinogenic for humans (1). Polycyclic aromatic hydrocarbons (PAH) and the PAH derivatives present in diesel exhaust are distributed between the gas and particulate phases of air (2). This distribution is determined by the vapor pressure, temperature, and concentration of individual species. The major organic compounds emitted by diesel engines have a low vapor pressure and are adsorbed on the particles before they leave the exhaust pipe. The carbon particles and the PAH and nitro-PAH adsorbed on their core constitute the specific particulate phase of diesel exhaust.

Chemical analyses of aromatic compounds measured in the volatile phase of tail-pipe emissions have shown that benzene is emitted in diesel exhaust. Benzene can be contained in fuel, and some amounts of it are produced during combustion $(3,4)$.

There is sufficient evidence that benzene is carcinogenic to humans $(1,5)$. Increased incidences of lymphoma have been found among humans exposed to benzene $(6,7)$. During recent years benzene has been shown to induce cancer types other than those related to the lymphohematopoietic system. Experimental investigations have demonstrated that benzene administration by inhalation induces different types of tumors in multiple organs $(8,9)$. An increased incidence of tumors of several sites, including lung, liver, and colon, was described for humans $(10,11)$. It is therefore reasonable to presume that benzene can take part in the carcinogenic process caused by diesel exhaust in lungs.

It should be noted that studies of diesel exhaust effects are limited to the particles, extracts from particles, or PAH and nitro-PAH, but contributions from volatile

1 Laboratory of Environmental Carcinogens, Institute of Experimental and Clinical Medicine, Tallinn, Estonia.

Reprint requests to: Dr V Muzyka, Laboratory of Environmental Carcinogens, Institute of Experimental and Clinical Medicine, Hiiu 42, EE0016 Tallinn, Estonia. [E-mail: muzyka@ekmi,online.ee] 
compounds such as benzene are not well recognized. However, the large core surface of carbon particles, low temperatures, and high humidity, and also the use of carbon filters for benzene adsorption from air, make it possible to assume that benzene may be associated with particles of diesel exhaust. Therefore the focus of this study was on analyzing the level of benzene bound to the particulate matter of diesel exhaust.

\section{Subjects and methods}

\section{Study design and subjects}

A bus garage was chosen for the location for assessing the benzene level of gas and particulate phases of dieselengine exhaust. The garage was a large confined building with some partitions in the middle. Both of the 2 large central parts contained 10 pits for bus reparation. Some workplaces for the repair of separate systems of buses were located on the periphery of this repair area. Areas for current repair and for scheduled repair were also located in the garage. Storage, engine warm-up, and reparation were performed in this garage. Refueling, brake tests, and washing took place in other buildings. This division of labor permitted the occurrence of such additional sources of benzene as the vapor phase of fuel to be excluded. [We could not completely exclude however the contribution from tobacco smoke to the atmospheric benzene concentration.]

About 200 workers were employed as maintenance workers in the bus garage. They work day and evening shifts as complex groups in the reparation of buses. Thirty-five male subjects were chosen for personal monitoring. All were nonsmokers who had worked in this garage more than 5 years. They were interviewed at their workplaces by trained researchers using structured questionnaires. Data were collected on age, job title, work location, known chemical exposure outside work, chronic and acute diseases, history of smoking, current consumption of alcoholic beverages, general health, and medication. There were 25 diesel fitters, 4 turners, 4 drivers for driving the buses within the garage, and 2 electricians. The workers' had worked from 5 to 22 (mean 12) years in their jobs. All the workers volunteered to wear passive monitors and active samplers.

\section{Sampling and analysis of air particles and benzene}

Personal passive monitors and active samplers were used for determining the total exposure to diesel exhaust. Passive monitors were used to adsorb benzene on carbon filters from the gas phase of the air in the workers' breathing zone. Individual active samplers collected particulate matter from the breathing zone and from the workplace atmosphere onto membrane filters (Millipore AAWP,
$0.8 \mu \mathrm{m}$ pore size) at a flow of $2.1 \mathrm{1} / \mathrm{min}$ during 8 workhours at a temperature of $13-15^{\circ} \mathrm{C}$ in winter and $18-20^{\circ} \mathrm{C}$ in summer. The cassettes with filters were carefully closed and were kept in cold containers for transfer to the laboratory, where the samples were analyzed immediately. The time-weighted concentration of particulate matter in the breathing zone over the work shift was determined for all the workers.

Dimethylformamide was used to extract benzene from the passive monitors and from particulate matter. As an eluent, dimethylformamide is well suited for extracting benzene from carbon particles. Its desorption efficiency (recovery coefficient) for benzene extraction from passive monitors is equal to 0.99. Moreover, dimethylformamide does not contain traces of benzene.

The levels of benzene in the gas phase and on the particles after elution from the filters were measured by a gas chromatograph equipped with a flame ionization detector and a DB-1/1.0 column.

\section{Statistical analysis}

Nonparametric tests were chosen for the statistical analysis because a lack of normality was found in several distributions of the benzene concentrations on particles and in the gas phase of air. The statistical ANOVA program (1-way analysis of variance on square-root-transformed data) was used to compare the obtained data. Differences were considered to be statistically significant at $\mathrm{P}<0.05$.

\section{Results}

The air of the garage contained an average of 0.42 (SD $0.19) \mathrm{mg} / \mathrm{m}^{3}$ suspended particulate matter. The range of suspended particulate matter in the workplace atmosphere was between 0.22 and $0.91 \mathrm{mg} / \mathrm{m}^{3}$. The higher concentrations of particles in the air $\left(1.4-5.7 \mathrm{mg} / \mathrm{m}^{3}\right)$ were observed near the bus with an operating diesel engine.

The concentration of benzene in the particulate samples from the breathing zone varied from 0.11 to 0.27 $\mathrm{mg} / \mathrm{g}$ of particulate matter. Its mean value of 0.15 (SD $0.14) \mathrm{mg} / \mathrm{g}$ corresponded to an average benzene concentration of 0.064 (SD 0.053$) \mu \mathrm{g} / \mathrm{m}^{3}$ in association with particles in a cubic meter of air. The concentration of benzene on the suspended particulate matter collected near the bus tailpipe during the operation of a diesel engine was between 0.47 and $0.81 \mathrm{mg} / \mathrm{g}$ of particles.

The diesel fuel blends used in the garage contained about $2.1 \%$ benzene. The mean benzene level in the gas phase of the garage air averaged 0.45 (SD 1.33) $\mathrm{mg} / \mathrm{m}^{3}$. At the same time the outdoor concentration of benzene was 0.015 (SD 0.010$) \mathrm{mg} / \mathrm{m}^{3}$. Short-term peak concentrations of $6.78 \mathrm{mg} / \mathrm{m}^{3}$ were measured for benzene in the 
garage air near the tailpipe when the diesel engines were started. This level of benzene rather quickly diminished as the distance from the bus increased (figure 1).

The concentrations of benzene in the breathing zone of the workers (in the gas phase and on particulate matter) are shown in table 1 for each part of the garage. The highest values were observed in the current repair area, where buses were changed more often, than in the scheduled repair area. The lowest levels of benzene were found in zones in which some electrical and mechanical systems were under repair. The individual levels of airborne benzene adsorbed by the personal monitors varied in a wide range (from 0.04 to $5.7 \mathrm{mg} / \mathrm{m}^{3}$ ).

The concentrations of benzene in the gas and particulate phases of the air and the contents of the particles in the garage air are shown for the winter and summer seasons in table 2. The level of benzene in the particulate phase was significantly elevated in winter, in spite of the
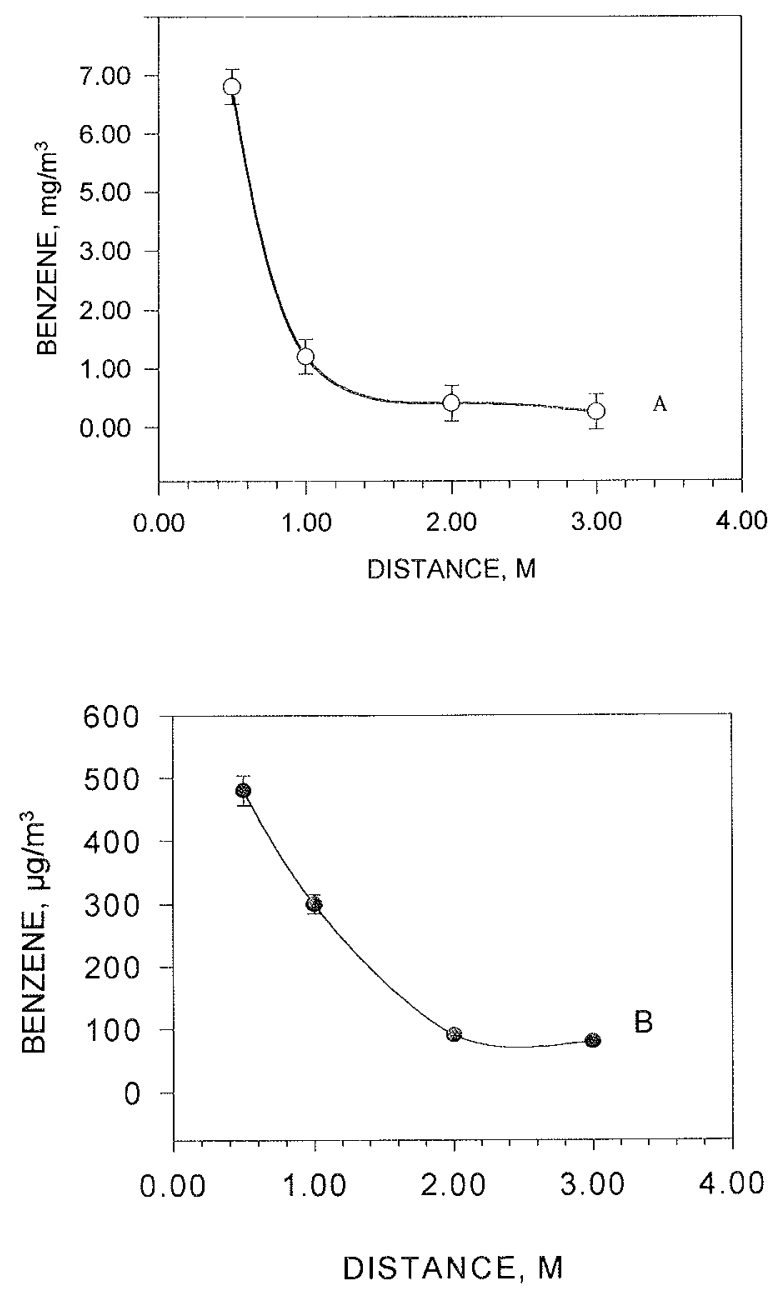

Figure 1. Relationship between the benzene level in bus garage air ( $A$ ) and in suspended particulate matter (B) and the distance from the operating diesel engine. decrease in particulate matter. The benzene increase in the gas phase of the garage air in winter was not statistically significant.

\section{Discussion}

It is well known that epidemiologic studies are applied better in situations with an elevated exposure, such as in work environments. Therefore, a bus garage was chosen for the determinations of benzene in the gas and particulate phases of air as an indicator of occupational exposure to diesel exhaust. Our data showed that diesel exhaust was the main source of benzene in the air of the bus garage since the majority of buses had been in use for more than 10 years and had old diesel motors, which emitted large amounts of exhaust gases. The diesel fuel in use contained $2.1 \%$ benzene. In addition, the benzene concentration decreased in the gas and particulate phases as the distance from the operating bus increased. High short-term peak concentrations of benzene near the tailpipe can lead to a dangerously fast increase in the benzene level of lung cells. In this connection the workers of this garage were exposed to a high level of diesel exhaust and, consequently, to high levels of benzene $[0.45$

Table 1. Benzene concentration in the gas and particulate phases of emissions in the breathing zone of the workers and the level of suspended particles in the ambient air of the bus garage.

\begin{tabular}{|c|c|c|c|c|c|c|c|}
\hline \multirow[t]{2}{*}{ Location } & \multirow[t]{2}{*}{$\begin{array}{l}\text { Number } \\
\text { of } \\
\text { samples }\end{array}$} & \multicolumn{2}{|c|}{$\begin{array}{l}\text { Benzene } \\
\text { in gas } \\
\text { phase } \\
\left(\mu \mathrm{g} / \mathrm{m}^{3}\right)\end{array}$} & \multicolumn{2}{|c|}{$\begin{array}{c}\text { Benzene } \\
\text { in } \\
\text { particulate } \\
\text { phase } \\
\left(\mu \mathrm{g} / \mathrm{m}^{3}\right)\end{array}$} & \multicolumn{2}{|c|}{$\begin{array}{c}\text { Particulate } \\
\text { matter } \\
\left(\mu \mathrm{g} / \mathrm{m}^{3}\right)\end{array}$} \\
\hline & & Mean & $\mathrm{SD}$ & Mean & $\mathrm{SD}$ & Mean & SD \\
\hline Current repair area & 9 & 430 & 121 & 0.099 & 0.024 & 574 & 121 \\
\hline Scheduled repair area & 15 & 350 & 90 & 0.065 & 0.017 & 480 & 93 \\
\hline Repair zone of bus systems & ns 17 & 298 & 67 & 0.044 & 0.015 & 368 & 109 \\
\hline Diesel repair zone & 9 & 232 & 54 & 0.032 & 0.013 & 237 & 73 \\
\hline
\end{tabular}

Table 2. Changes in the benzene concentration of the breathing zone of the workers and in the particulate matter of the garage air, depending on season of year.

\begin{tabular}{|c|c|c|c|c|c|c|c|}
\hline \multirow[t]{2}{*}{ Season } & \multirow[t]{2}{*}{$\begin{array}{c}\text { Number } \\
\text { of } \\
\text { samples }\end{array}$} & \multicolumn{2}{|c|}{$\begin{array}{l}\text { Benzene } \\
\text { in gas } \\
s \text { phase } \\
\left(\mu g / \mathrm{m}^{3}\right)\end{array}$} & \multicolumn{2}{|c|}{$\begin{array}{c}\text { Benzene } \\
\text { in } \\
\text { particulate } \\
\text { phase } \\
\left(\mu \mathrm{g} / \mathrm{m}^{3}\right)\end{array}$} & \multicolumn{2}{|c|}{$\begin{array}{c}\text { Benzene } \\
\text { in } \\
\text { particulate } \\
\text { matter } \\
\left(\mu g / g^{3}\right)\end{array}$} \\
\hline & & Mean & SD & Mean & SD & Mean & $\mathrm{SD}$ \\
\hline Winter & 35 & 354 & 212 & 0.066 & 0.017 & 194 & 15 \\
\hline Summer & 35 & 295 & 167 & 0.035 & $0.018 *$ & 73 & $6^{*}$ \\
\hline
\end{tabular}

* $P<0.05$, comparison of winter and summer values. 
(SD 1.33 ) $\left.\mathrm{mg} / \mathrm{m}^{3}\right]$, as one of its volatile components. At the same time Swedish investigators have found the mean concentration of airborne benzene to be lower than 0.2 $\mathrm{mg} / \mathrm{m}^{3}$ in bus garages (12).

Small amounts of benzene [0.15 (SD 0.14) $\mathrm{mg} / \mathrm{g}$ of particles or 64.1 (SD 58.4) $\mu \mathrm{g}$ of benzene in connection with particles contained in $1.0 \mathrm{~m}^{3}$ of breathing-zone air] were associated with particulate matter continually suspended in air. Water vapor can condense on the core of particles with the fall of diesel exhaust temperature. Benzene has a relative preference for water over air. [According to Hunt (13) the air-water partition coefficient is 0.22 .] Therefore, benzene can diffuse from the gas phase to the water film of the particles. However, whether this association is adsorption or condensation is unknown. The amounts of benzene on the particles are comparable with the concentration of $\mathrm{PAH}$ and nitro-PAH adsorbed on diesel exhaust particles. For example, the average concentration determined in the ambient air of Göteborg was $20 \mathrm{ng} / \mathrm{m}^{3}$ for PAH and $10 \mathrm{ng} / \mathrm{m}^{3}$ for $1-$ nitropyrene (14). The carcinogenic effect of PAH is enhanced by adsorption on particles (15). The mechanism of this action has remained unknown. However, this adsorption onto particles has been shown to increase the retention time of PAH and nitro-PAH in lung tissue, partly by decreasing the rate of metabolism $(1,16)$. Therefore, on one hand, a small amount of benzene connected with respirable particles can modify the cancer risk as a potential cocarcinogen, promoter, or inhibitor. On the other hand, the association of benzene with the core of particles can lead to changes in the structure of the benzene molecule and to further oxidation of it.

Diesel fuel is produced commercially in various qualities with regard to levels of volatile aromatic compounds, the cetane number, and the sulfur content. The composition of diesel fuel influences the type and amount of compounds emitted in the exhaust. Diesel fuel composition differs in winter and summer in Nordic countries. However, the same winter-quality diesel fuel was used in the Tallinn Municipal Bus Garage in February and June, when the airborne benzene concentrations were measured. Therefore no difference in fuel quality existed for the benzene levels of the garage air. These results indicate that distinct seasonal variation occurred only for the concentration of benzene associated with particles. The concentration was significantly lower in summer than in winter, and it matched the seasonal decrease of $\mathrm{PAH}$ and benzo[a]pyrene $(14,17)$. The condensation of benzene on particles probably depended on the ambient temperature. The statistically insufficient decrease in the airborne benzene level in summer can be explained by insignificant seasonal changes in temperature in the garage, from $13-15^{\circ} \mathrm{C}$ in winter to $18-20^{\circ} \mathrm{C}$ in summer.

Thus our results indicate that the primary source of benzene in the air of bus garages is diesel exhaust. Ben- zene is adsorbed on the particles of suspended particulate matter. The concentration of benzene in the gas phase or in the suspended particulate matter or both of bus garage air can serve as an additional indicator of exposure to diesel exhaust and its carcinogenicity. The concentration of benzene in the breathing zone of workers undergoes fluctuation depending on the distance from the operating diesel engine, type of work, and season.

\section{Acknowledgments}

We would like to thank the administration and staff of the Tallinn Municipal Bus Company for their excellent cooperation during this investigation.

This work was supported by a grant from the European Commission under contract number ERBCIPDCT940201.

\section{References}

1. International Agency for Research on Cancer (IARC). Diesel and gasoline engine exhausts and some nitroarenes. Lyon: IARC, 1989:35-6. IARC monographs on the evaluation of carcinogenic risks to humans, vol 46 .

2. Atkinson R, Arey J. Atmospheric chemistry of gas-phase polycyclic aromatic hydrocarbons: formation of atmospheric mutagens. Environ Health Perspect 1994;102 suppl 4:11726.

3. Westerholm R, Egebäck K-E. Exhaust emissions from lightand heavy-duty vehicles: chemical composition, impact of exhaust after treatment, and fuel parameters. Environ Health Perspect 1994;102 suppl 4:13-25.

4. Wallace LA. Major sources of benzene exposure. Environ Health Perspect 1989;82:165-9.

5. Medinsky MA. A review of the toxicokinetics of benzene. In: Mohr U, editor. Assessment of inhalation hazards. Berlin: Springer, 1989:215-24.

6. Young N. Benzene and lymphoma. Am J Ind Med 1989;15:495-8.

7. Rinsky RA, Smith AB, Hornung R, Fillon TG, Young RJ, Okun $\mathrm{AH}$, et al. Benzene and leukaemia, epidemiological risk assessment. N Engl J Med 1987;316:1044-50.

8. Huff JE, Haseman JK, De Marini DM, Enstis S, Maronpot RR, Poters AC, et al. Multiple-site carcinogenicity of benzene in Fischer 344 rats and B6C3F1 mice. Environ Health Perspect $1989 ; 82: 125-63$.

9. Maltoni C, Ciliberti A, Cotti G, Conti B, Belpoggi F. Benzene, an experimental multipotential carcinogen: results of long-term bioassays performed at the Bologna Institute of Oncology. Environ Health Perspect 1989;82:109-24.

10. Yin S-N, Li G-L, Tain F-D, Fu Z-N, Jin C, Chen Y-J, et al. A retrospective cohort study of leukemia and other cancer in benzene workers. Environ Health Perspect 1989;82:207-13.

11. Gustavsson P, Plato N, Lindström E-B, Hogstedt C. Lung cancer and exposure to diesel exhaust among bus garage workers. Scand J Work Environ Health 1990;16:348 - 54. 
12. Ulfvarson U, Alexandersson R, Aringer L, Swensson E, Hedenstierna G, Hogstedt C, et al. Effects of exposure to vehicle exhaust on health. Scand J Work Environ Health 1987; 13:505-12.

13. Hunt JR, Holden PA, Firestone MK. Coupling transport and biodegradation of VOCs in surface and subsurface soils. Environ Health Perspect 1995;103 suppl 5:75-8.

14. Boström CE, Almen J, Steen B, Westerholm R. Human exposure to urban air pollution. Environ Health Perspect 1994;102 suppl 4:39-47.

15. Törnqvist M, Ehrenberg L. On cancer risk estimation of urban air pollution. Environ Health Perspect 1994;102 suppl 4:173-
81.

16. Warshawsky D, Bingham E, Niemeier RW. Influence of airborne particulate on the metabolism of benzo[a]pyrene in the isolated perfused lung. J Toxicol Environ Health 1983;11:503-17.

17. Chorazy M, Szeliga J, Strozyk M, Cimander B. Ambient air pollutants in Upper Silesia: partial chemical composition and biological activity. Environ Health Perspect 1994;102 suppl $4: 61-6$.

Received for publication: 11 February 1998 